\title{
Travel To High Burden Tuberculosis Country
}

National Cancer Institute

\section{Source}

National Cancer Institute. Travel To High Burden Tuberculosis Country. NCI Thesaurus.

Code C102719.

Entry into one or more of the 22 countries that have a relatively high prevalence of tuberculosis cases. 